\title{
Assessment of Anticoccidial Efficacy of Novel Triazine Compound and Sulfaclozine against Experimentally Induced Caecal Coccidiosis in Broiler Chickens
}

(Penilaian Keberkesanan Antikoksidia Sebatian Baru Triazina dan Sulfaklozina terhadap Koksidiosis Sekum Teraruh Uji Kaji dalam Ayam Pedaging)

\author{
Dina HagaG*, Kamal El-Shazly, Magdy Abd El-Aziz, Amira Abd El-Latif, Hanem El-SharkaWAY, \\ WALIED ABDO \& MOHAMED BARAKAT
}

\begin{abstract}
This study was performed to investigate the theraputic efficacy of toltrazuril, sulfaclozine sodium and their combination in broiler chicken for the treatment of experimentally induced caecal coccidiosis. For this purpose, seventy-five day-old chicks were randomly divided into five equal groups (15 each). $G_{1}$, kept as control negative; $G_{2}$, infected non treated (control positive); $G_{3}$, infected treated with toltrazuril $(1 \mathrm{~mL} / \mathrm{L}) ; G_{4}$, infected treated with sodium sulfaclozine $(2 \mathrm{~mL} / \mathrm{L}) ; G_{5}$, infected treated with toltrazuril $(1 \mathrm{~mL} / \mathrm{L})+$ sulfaclozine $\mathrm{Na}(2 \mathrm{~g} / \mathrm{L})$. All groups except negative control group were inoculated orally with $5 \times 10^{4}$ sporulated oocysts of Eimeria tenella (field isolate) on the day $15^{\text {th }}$ of age. According to the present results, $G_{2}$ showed a significant increase in oocyst count, AST, ALT, $A L P$, uric acid, and creatinine, with significant decrease in body weight gain, hematological parameters, total protein, and albumin. Treatment decreased the harmful effect of infection but some significant differences were shown between infected and treated groups and non infected and non treated group in assessment criteria. Furthermore, the histopathological findings were also discussed. In conclusion, the current study showed that the application of both tested drugs gave significant and satisfactory improvement in the assessment criteria as well as they are effective in control of coccidiosis caused by Eimeria tenella.
\end{abstract}

Keywords: Broiler; E. tenella experimental infection; Egypt; sulfaclozine sodium; toltrazuril

\section{ABSTRAK}

Kajian ini dilakukan untuk mengkaji keberkesanan terapeutik toltrazuril, natrium sulfaklozina dan gabungannya pada ayam pedaging untuk rawatan terhadap koksidiosis sekum teraruh uji kaji. Bagi tujuan ini, anak ayam berusia tujuh puluh lima hari dibahagikan secara rawak masing-masing kepada lima kumpulan yang sama (15 kumpulan). $G_{1}$, sebagai kawalan negatif; $G_{2}$, dijangkiti dan tidak dirawat (kawalan positif); $G_{3}$, dijangkiti dan dirawat dengan toltrazuril ( $1 \mathrm{~mL} / \mathrm{L}) ; G_{4}$, dijangkiti dan dirawat dengan natrium sulfaklozina $(2 \mathrm{~g} / \mathrm{L}) ; \mathrm{G}_{5}$, dijangkiti dan dirawat dengan toltrazuril $(1 \mathrm{~mL} / \mathrm{L})+$ natrium sulfaklozina $(2 \mathrm{~g} / \mathrm{L})$. Semua kumpulan kecuali kumpulan kawalan negatif disuntik secara lisan dengan $5 \times 10^{4}$ oosista sporulasi bagi Eimeria tenella (medan terasing) pada hari ke-15. Hasilnya, G menunjukkan peningkatan yang signifikan dalam jumlah oosistacre, AST, ALT, ALP, asid urik dan kreatinin, dengan penurunan yang signifikan dalam kenaikan berat badan, parameter hematologi, jumlah protein dan albumin. Rawatan telah mengurangkan kesan berbahaya disebabkan jangkitan tetapi beberapa perbezaan ketara ditunjukkan antara kumpulan yang dijangkiti dan dirawat dan kumpulan yang tidak dijangkiti dan tidak dirawat dalam kriteria penilaian. Tambahan pula, penemuan histopatologi juga dibincangkan. Kesimpulannya, kajian semasa menunjukkan bahawa penggunaan kedua-dua ubat yang diuji memberikan peningkatan yang ketara dan memuaskan dalam kriteria penilaian serta berkesan juga dalam mengendalikan koksidiosis yang disebabkan oleh Eimeria tenella.

Kata kunci: Ayam pedaging; jangkitan uji kaji E. tenella; Mesir; natrium sulfaklozina; toltrazuril

\section{INTRODUCTION}

Chickens considered as a good source of high biological value animal protein for human consumption. Rising of public awareness of the poultry industry will likely continue to make proper prevention and treatment of several diseases, of which avian coccidiosis. Coccidiosis is still major problems worldwide; caused by a single-cell protozoan parasite belonging to the genus Eimeria. It has a significant economic impact on poultry by reducing performance and decreasing productivity, with high rate of mortality and morbidity (Abbas et al. 2017). Conventional control of this problem based mainly on managerial skills 
and the use of anticoccidial drugs (Tewari \& Maharana 2011).

Synthetic anticoccidial drugs remain the mainstream agents used in control of chicken coccidiosis globally. Moreover, anticoccidial compounds should be highly effective against all developmental stages of Eimeria species, do not disturb the host immune response as well as have no residues in the tissues. In this respect, Toltrazuril, a triazinetrione derivative is licensed drug for not only as prophylactic agent but also as curative drugs against all developmental stages of Eimeria spp. (Shivaramaiah et al. 2014). Toltrazuril interferes with the division of the nucleus and with the activity of the mitochondria, which is responsible for the respiratory metabolism of Coccidia. In the macrogamete, toltrazuril damages the so-called wall-forming bodies. In all intracellular developmental stages, severe vacuolization occurs due to inflation of the endoplasmic reticulum (Harfoush et al. 2010; Ramadan et al. 1997).

On the other hand, Sulfaclozine sodium is an efficacious sulphonamide derivative with antibacterial and anticoccidial effect ( $\mathrm{Li} \& \mathrm{Bu} 2014$ ). As other sulfonamides, it has a good coccidiostatic effects on control and treatment of chicken coccidiosis in experimental and natural infection (McDougald \& FitzCoy 2008). Sulfaclozine is a competitive antagonist of paraaminobenzoic acid (PABA), a precursor of folic acid, in protozoa and bacteria. Folic acid is a coenzyme necessary for the synthesis of nucleic acid; hence sensitive species do not multiply in the presence of sulfaclozine (Harfoush et al. 2010). Furthermore, feeding of sulfonamides may prevent clinical signs and reduce oocyst production thereby allowing development of protective immunity.

As the world's poultry industry continues to grow, so does concerns about the control of coccidiosis, which remains one of the most commonly reported disease of chickens (Xie et al. 2001). Therefore, the present study was conducted to investigate the anticoccidial efficacy of toltrazuril, sulfaclozine sodium and their simultaneous use against experimentally induced E. tenella in broiler chickens.

\section{MATERIALS AND METHODS}

\section{DRUGS}

Toltrazuril oral solution (Kimzuril 2.5\%®), each $100 \mathrm{~g}$ containing $2.5 \mathrm{~g}$ toltrazuril. It is recommended at level of $1 \mathrm{~mL}$ kimzuril/liter of drinking water for three successive days. Sulfaclozine sodium monohydrate water soluble powder (sulfaclozimed $30 \% \AA$ ), each $100 \mathrm{~g}$ contains $30 \mathrm{~g}$ sulfaclozine sodium monohydrate. It is recommended at level of $2 \mathrm{~g}$ sulfaclozimed/liter of drinking water for three successive days. The two drugs were purchased from Arab company for medical products, Egypt.

\section{EXPERIMENTAL BIRDS}

A total of 75 one-day old Erbo plus strain chicks from Taraq Deiab Farm, Kotor, Egypt with an average body weight of 45 to $50 \mathrm{~g}$ were used in these trials. The birds were kept in individual well-isolated floor pens with wood shaving litter, plastics waters, and feeders. All tested birds were fed a standard commercial diet and were formulated without any anticoccidial medication (Abd ElSalam Hegazy Company, Cairo, Egypt). Strict sanitation practices were maintained in the experimental house before and during the course of experiment. Temperature was adjusted according to the age (at the first week of age it was $32{ }^{\circ} \mathrm{C}$ and decreased $2{ }^{\circ} \mathrm{C}$ per week till reached 26 ${ }^{\circ} \mathrm{C}$ at one month of age and was fixed at this degree till the end of experiment. Continuous light was also provided throughout the experimental period (Harrison \& Harrison 1986). Furthermore, Birds were vaccinated against infectious bronchitis, Newcastle disease and infectious bursal disease according to the standard schedule.

\section{PREPARATION OF Eimeria INFECTION}

Eimeria tenella oocysts were collected from ceci of naturally infected chickens. The infected chickens were selected from a commercial broiler farm obtained from Alpha Laboratory, Gharbia governorate, Egypt. The protocol of isolation and preparation of E. tenella oocyst was performed according to Lovelu et al. (2016). The cecal contents were homogenized with water and sieved in a beaker through a fine wire mesh. The filtrate was let to sediment, the supernatant was discarded and the pellet was re-suspended in potassium dichromate $2.5 \%$ in the presence of suitable humidity and temperature in a group of petri dishes. The thickness of fluid was not higher than $5 \mathrm{~mm}$ to facilitate the oxygen diffusion. Forced aeration was achieved (2-3 time daily) by removing the cover and shaking the suspension for few minutes. The plates were examined microscopically to assign the degree of sporulation. After sporulation, the sporulated oocysts were removed from the fecal debris by a series of centrifugation using $\mathrm{NaCl}$ (concentration flotation technique). The suspension was centrifuged at a moderate speed (1500 rpm) for 5-10 min to allow the oocysts to suspend at the top of supernatant and sediment the solids. The floated oocysts were collected by Pasteur pipette. Sporulated oocysts count (oocysts per gram of feces, OPG) was estimated by the use of the Mc Master technique (Lloyd \& Soulsby 1978). The coccidial species were microscopically identified following its sporulation in $2.5 \%$ solution by using morphological parameters (Eckert et al. 1995).

\section{EXPERIMENTAL DESIGN}

The chickens were weighed and randomly divided at $15^{\text {th }}$ day of age into five equal groups (each of 15) as the following: 
Group $_{1}$ : non-infected non treated (control negative). Group $_{2}$ : infected non treated (control positive). Group : $_{3}$ infected treated with toltrazuril $(1 \mathrm{~mL} / \mathrm{L})$. Group 4 : infected treated with sulfaclozine sodium $(2 \mathrm{~g} / \mathrm{L})$. Group 5 : infected treated toltrazuril with $(1 \mathrm{~mL} / \mathrm{L})+$ sulfaclozine sodium ( $2 \mathrm{~g} / \mathrm{L})$.

Except $\mathrm{G}_{1}$, all groups were infected with $5 \times 10^{4}$ oocysts of E. tenella (field isolate) orally by direct administration into the crop using rubber syringe on day $15^{\text {th }}$ of the experiment (Harfoush et al. 2010). Moreover, the application of drug treatment was started at day $20^{\text {th }}$ of age and continued for three successive days.

\section{ASSESSMENT CRITERIA}

\section{CLINICAL SIGNS AND GROWTH PERFORMANCE MEASUREMENTS}

Throughout the experiment, the morbidity and the numbers of dead birds were recorded daily representing the mortality rate, beside any obvious clinical signs were also recorded. Furthermore, birds were individually weighted weekly, beginning from $15^{\text {th }}$ day of age. The weight gain was calculated by subtracting the initial weight of birds from the final weight of the birds. Feed conversion ratio (FCR) was calculated using the following formula: $\mathrm{FCR}=$ Feed consumption in a given period/ gain produced in the same period (El-Ghoneimy \& ElShahawy 2017).

\section{NUMBER OF OOCYSTS PER GRAM (OPG) OF FAECES}

The reduction of oocyst output was taken as a criterion for the efficacy of tested drugs. The faecal samples were collected on day 0 (pretreatment) at 20 days old and consequently at day 1 till 13 days post coccidian treatment (from 21 till 33 days old). The oocysts counting were done through Mc Master Techniques as described by Chand et al. (2016). Additionally, the percentage efficacy for tested drugs was determined (Moskey \& Harwood 1941).

\section{LESION SCORE}

Five birds were sacrificed/group at $8^{\text {th }}$ and $22^{\text {nd }}$ days post infection for demonstration of macroscopical caecal lesion score. The lesions were scored on a scale of 0 to +4 according to the severity of the lesions (Johnson \& Reid 1970). A score (0) denoted no lesions whereas (+4) denoted severe lesion.

\section{HEMATOLOGICAL AND BIOCHEMICAL ANALYSIS}

Two blood samples were collected from each group (five birds/group) at $23^{\text {th }}$ and $37^{\text {th }}$ days of age. For hematological parameters, about $1 \mathrm{~mL}$ of blood was withdrawn from the wing vein and immediately transferred into sterile test tube containing $1 \mathrm{mg}$ EDTA as an anticoagulant. Complete blood picture (hemoglobin concentration, packed cell volume, red blood cell count, white cells count, and differential leucocyte count) were calculated (Reagan et al. 2019). For biochemical analysis on the other hand, blood was collected without anticoagulant for serum biochemistry determination. Serum was separated after centrifugation at $3000 \mathrm{rpm}$ for 15 min and stored at $-20{ }^{\circ} \mathrm{C}$ until tested. Serum aspartate aminotransferase (AST), alanine aminotransferase (ALT) (Reitman \& Frankel 1957), alkaline phosphates (Kind \& King 1954), total serum protein (Henry 1964), albumin (Doumas et al. 1971), creatinine (Henry 1974) and uric acid (Barham \& Trinder 1972) were measured.

\section{HISTOPATHOLOGICAL EXAMINATION}

Tissue specimens from cecum, liver, and kidney were taken from chickens in all groups (five birds/group) at the day $23^{\text {th }}$ and $30^{\text {th }}$ of age. Specimens fixed in $10 \%$ neutral formalin before dehydration in ascending grading of ethyl alcohol, followed by clearing in xylene and processed in paraffin wax cubes. Specimens cubes were sectioned at $5 \mu \mathrm{m}$ thickness, then stained with haematoxylin and eosin (H\&E) according to the method described by Pop et al. (2015). The count of the parasitic stages within the intestinal tissues was performed blindly and expressed as the average number $/ \mathrm{mm}^{2}$ in about $8 \mathrm{HPF}$. Regarding to histological scoring of both hepatic and renal lesions, eight points score was assessed according 4 parameters ( 2 points to each) including vascular lesions as congestion and hemorrhage, degenerative changes, necrosis, and inflammation. Each parameter was assessed as 0 no obvious lesions, 1 mild changes and 2 advanced diffuse changes.

\section{STATISTICAL ANALYSIS}

All the data were expressed as means \pm standard deviation (SD). The statistical significance evaluated by one-way analysis of variance (ANOVA) using the statistical software program (SPSS, ver.16.00, USA). Values were considered statistically significant at $(p \leq 0.05)$.

\section{RESULTS}

\section{CLINICAL SIGNS AND MORTALITY RATE}

In this study, the birds in the infected non treated group $\left(G_{2}\right)$ showed ruffled feathers, huddling, depression, loss of appetite, anorexia, and intensive bloody diarrhea, which began on the $6^{\text {th }}$ day post-infection. These signs severed by $7^{\text {th }}$ day post-infection and subsided gradually with the observation of few discolored droppings and varying degrees of depression until the end of the experiment. This signs declined after treatment with toltrazuril $\left(\mathrm{G}_{3}\right)$, and sulfaclozine sodium $\left(\mathrm{G}_{4}\right)$ each alone or in combination $\left(\mathrm{G}_{5}\right)$ and chickens were more apparently healthy during this period. Moreover, the mortality $\%$ in $\mathrm{G}_{2}$ was $33.33 \%$ and it 
was reduced to $13.33 \%$ in $\mathrm{G}_{4}$, with no mortality observed in $\mathrm{G}_{3}, \mathrm{G}_{5}$ (Table 2).

\section{GROWTH PERFORMANCE}

Infected non treated group $\left(\mathrm{G}_{2}\right)$ showed a significant $(\mathrm{p} \leq 0.05)$ decrease in the body weight gain with poor feed conversion ratio. Moreover, there was a significant improvement in these growth performance parameters in $\mathrm{G}_{3}, \mathrm{G}_{4}$ and $\mathrm{G}_{5}$ as compared with $\mathrm{G}_{2}$ (Table 1 ).

\section{OOCYST OUTPUT AND LESION SCORE}

The infected non treated control group $\left(\mathrm{G}_{2}\right)$ showed the highest oocyst counting which reached its maximum count on the 8th day post infection. This highest oocyst counting was significantly decreased after treatment with toltrazuril $\left(\mathrm{G}_{3}\right)$ and sulfaclozine sodium $\left(\mathrm{G}_{4}\right)$ each alone or in combination $\left(\mathrm{G}_{5}\right)$ (Table 3 ). Based on percentage of reduction in the OPG in faeces, it can be concluded that the combination between Toltrazuril and Sulfaclozine sodium $\left(\mathrm{G}_{5}\right)$ was superior followed by Toltrazuril alone $\left(\mathrm{G}_{3}\right)$ and Sulfaclozine sodium alone $\left(\mathrm{G}_{4}\right)$, respectively (Table 3). On the other hand, the caeca of the infected non treated group $\left(\mathrm{G}_{2}\right)$ showed the highest lesion scores which ranged from +3 to +4 . The lesion scores were improved by all drugs treatments and ranged from +1 to +2 in $G_{4}$ and from 0 to +1 in $\mathrm{G}_{3}, \mathrm{G}_{5}$.

\section{HEMATOLOGICAL AND BIOCHEMICAL PARAMETERS}

Infected non treated group $\left(\mathrm{G}_{2}\right)$ showed a significant decrease in RBCs count, $\mathrm{Hb}$ concentration and $\mathrm{PCV} \%$ at $23^{\text {th }}$ and $37^{\text {th }}$ days of age compared with control group $\left(G_{1}\right)$. This decreased number was significantly increased after treatment with toltrazuril $\left(\mathrm{G}_{3}\right)$ and sulfaclozine sodium $\left(\mathrm{G}_{4}\right)$ each alone or in combination $\left(\mathrm{G}_{5}\right)$. There was a marked increase of the total leucocytic count, lymphocytes, heterophils, monocytes, and eosinophils in infected non treated group $\left(\mathrm{G}_{2}\right)$ and treated groups $\left(\mathrm{G}_{3}, \mathrm{G}_{4}, \mathrm{G}_{5}\right)$ then changed by time towards the normal value till the end of the experiment. With regarding $\mathrm{G}_{2}$, there was a significant increase in total leucocytic count and eosinophils at 37 days of age when compared with $\mathrm{G}_{1}$ (Tables 4 \& 5).

Infected non treated group $\left(\mathrm{G}_{2}\right)$ showed a significant increase in serum AST, ALT, ALP, uric acid, and creatinine, with a significant decrease in total protein and albumin compared with $\mathrm{G}_{1}$ at $23^{\text {th }}$ and $37^{\text {th }}$ days of age. Moreover, infected treated groups $\left(\mathrm{G}_{3}, \mathrm{G}_{4}, \mathrm{G}_{5}\right)$ showed a significant decrease in AST, ALT, uric acid, and creatinine and a significant increase in total protein and albumin compared with $\mathrm{G}_{2}$ (Tables 6 \& 7).

\section{HISTOPATHOLOGICAL FINDINGS}

Quantitative scoring of the histopathological findings as illustrated in Figures 1 to 3 . The cecal, hepatic, and renal scores markedly elevated in $\mathrm{G}_{2}$. While the different tissue scores decreased in treated groups $\left(\mathrm{G}_{3}, \mathrm{G}_{4}, \& \mathrm{G}_{5}\right)$. The parasitic stages count in cecal tissue significantly reduced in all treated groups. $\mathrm{G}_{5}$ showed a significant decrease of coccidial stages in comparison with $\mathrm{G}_{3}$ and $\mathrm{G}_{4}(\mathrm{P} \leq 0.05)$. However, the hepatic and renal scores in $\mathrm{G}_{5}$ did not show any significance in compared with every single treatment.

On the $23^{\text {rd }}$, the histological examination of cecal sections of $G_{1}$ showed normal mucosal folds with normal intestinal crypts. $G_{2}$ showed necrotic enteritis associated with partial or complete sloughing of the mucosa as most of intestinal gland showed presence of coccidial schizonts. Some of the parasitic stages were extended to the muscle layer associated with extensive necrosis, inflammation, and marked inflammatory cells infiltrated such as heterophils, eosinophils, and mononuclear cells. $\mathrm{G}_{3}$ showed a marked decrease in the necrotic lesion accompanied by decreasing the parasitic stages within lining mucosa and hyperplastic regenerative changes seen within the mucosal lining. Similarly, $\mathrm{G}_{4}$ showed to decrease the parasitic stages and necrotic enteritis but with a lesser degree than $\mathrm{G}_{3}$. $\mathrm{G}_{5}$ showed a marked decrease in parasitic stages, mild degenerative and hyperplastic changes within the mucosa. The liver of $G_{1}$ showed normal hepatic tissues. $G_{2}$ showed multifocal periportal inflammation consisted of mononuclear cell infiltration mixed with eosinophils. $G_{3}$ showed a mild to moderate degree of portal inflammation. $\mathrm{G}_{4}$ showed to a marked degree of hepatic vacuolation and degeneration. The liver of $\mathrm{G}_{5}$ showed periportal inflammatory cell infiltration. The kidney of $\mathrm{G}_{1}$ showed normal renal glomeruli and tubules. $\mathrm{G}_{2}$ demonstrated coagulative necrosis of the renal tubules. $\mathrm{G}_{3}$ showed mild degenerative change of renal tubules. $G_{4}$ showed degenerative changes within the renal tubules such as vacuolation, myelin membrane on the renal tubules epithelial lining and hyaline cast. $\mathrm{G}_{5}$ showed similar lesions of $\mathrm{G}_{4}$.

On the $37^{\text {th }}$, the cecal mucosa was improved than the previous sacrifice, unless $\mathrm{G}_{2}$ showed the still presence of parasitic stages seen within the lamina propria and muscle layer. Meanwhile, $\mathrm{G}_{3}, \mathrm{G}_{4}$, and $\mathrm{G}_{5}$ showed a marked decrease of coccidial stages which mostly noticed as a dead vacuolated cyst. The liver of $\mathrm{G}_{2}$ showed still periportal inflammation consisted mainly of mononuclear cells and an abundant number of eosinophils. Also, the kidney showed degenerative changes within the renal tubules with marked regenerative tubular basophilia. The liver and kidney of $G_{3}$ were showed mild lesion while $G_{4}$ and $\mathrm{G}_{5}$ showed moderate degenerative changes of the renal tubular epithelium. 
TABLE 1. Body weight gain (g) and feed conversion ratio (FCR) (mean \pm SD) in control and treated groups

\begin{tabular}{|c|c|c|c|c|c|c|}
\hline \multirow[b]{2}{*}{ Groups } & \multicolumn{3}{|c|}{ Body wt. gain } & \multicolumn{3}{|c|}{ Feed conversion ratio (FCR) } \\
\hline & At day 22 & At day 29 & At day 36 & At day 22 & At day 29 & At day 36 \\
\hline $\mathrm{G}_{1}$ & $444.7 \pm 12.15^{\mathrm{a}}$ & $591.05 \pm 25.97^{\mathrm{a}}$ & $714.09 \pm 25.14^{\mathrm{a}}$ & $1.38 \pm 0.02^{\mathrm{c}}$ & $1.35 \pm 0.03^{\mathrm{c}}$ & $1.49 \pm 0.06^{\mathrm{c}}$ \\
\hline $\mathrm{G}_{2}$ & $264.79 \pm 11.15^{\mathrm{c}}$ & $524.13 \pm 11.24^{b}$ & $527.27 \pm 30.59^{b}$ & $1.89 \pm 0.05^{\mathrm{a}}$ & $1.43 \pm 0.01^{\mathrm{a}}$ & $1.7 \pm 0.01^{\mathrm{a}}$ \\
\hline $\mathrm{G}_{3}$ & $352.6 \pm 13.76^{b}$ & $585.59 \pm 14.15^{\mathrm{a}}$ & $683.46 \pm 20.19^{\mathrm{a}}$ & $1.68 \pm 0.03^{\mathrm{b}}$ & $1.31 \pm 0.02^{\mathrm{b}}$ & $1.59 \pm 0.05^{\mathrm{b}}$ \\
\hline $\mathrm{G}_{4}$ & $344.67 \pm 16.76^{b}$ & $584.33 \pm 16.35^{\mathrm{a}}$ & $674.23 \pm 17.73^{\mathrm{a}}$ & $1.71 \pm 0.06^{\mathrm{b}}$ & $1.30 \pm 0.03^{\mathrm{b}}$ & $1.6 \pm 0.02^{\mathrm{b}}$ \\
\hline $\mathrm{G}_{5}$ & $338.93 \pm 19.73^{b}$ & $587.56 \pm 16.14^{\mathrm{a}}$ & $690 \pm 19.16^{\mathrm{a}}$ & $1.77 \pm 0.02^{\mathrm{b}}$ & $1.32 \pm 0.01^{\mathrm{b}}$ & $1.57 \pm 0.03^{\mathrm{b}}$ \\
\hline
\end{tabular}

Means within rows with different superscripts differ at $P \leq 0.05 . \mathrm{G}_{1}$ : Non-infected non-treated. $\mathrm{G}_{2}$ : Infected non-treated. $\mathrm{G}_{3}$ : Infected, treated by toltrazuril. $\mathrm{G}_{4}$ : Infected, treated by sulfaclozine sodium. $\mathrm{G}_{5}$ : Infected, treated by toltrazuril + sulfaclozine sodium

TABLE 2. Lesion score and mortality \% in control and treated groups

\begin{tabular}{ccccc}
\hline & \multicolumn{2}{c}{ Lesion score } & & \\
\cline { 2 - 3 } Group & At $23^{\text {th }}$ day & At $37^{\text {th }}$ day & NO. of deaths & Mortality \% \\
\hline $\mathrm{G}_{1}$ & 0 & 0 & 0 & 00.00 \\
$\mathrm{G}_{2}$ & +4 & +3 & 5 & 33.33 \\
$\mathrm{G}_{3}$ & +1 & 0 & 0 & 00.00 \\
$\mathrm{G}_{4}$ & +2 & +1 & 2 & 13.33 \\
$\mathrm{G}_{5}$ & +1 & 0 & 0 & 00.00
\end{tabular}

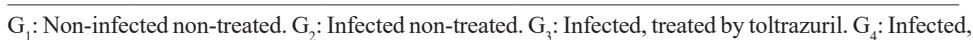
treated by sulfaclozine sodium. $\mathrm{G}_{5}$ : Infected, treated by toltrazuril + sulfaclozine sodium

TABLE 3. Oocysts count $\left(\times 10^{3}\right) /$ gram of feces $(\mathrm{OPG})(\mathrm{mean} \pm \mathrm{SD})$ and $\%$ of OPG reduction $(\mathrm{OPGR} \%)$ in infected non treated and treated groups $(\mathrm{N}=5)$

\begin{tabular}{|c|c|c|c|c|c|}
\hline \multirow[t]{2}{*}{ Age } & \multirow[t]{2}{*}{ Group } & \multicolumn{4}{|c|}{ Infected groups oocyst count $\left(\times 10^{3}\right) /$ gm feaces } \\
\hline & & $\mathrm{G}_{6}$ & $\mathrm{G}_{7}$ & $\mathrm{G}_{8}$ & \\
\hline \multicolumn{2}{|c|}{ (20 day) } & $461.00 \pm 11.21^{\mathrm{a}}$ & $378.31 \pm 13.73^{\mathrm{a}}$ & $392.10 \pm 16.35^{\mathrm{a}}$ & $367.21 \pm 11.18^{\mathrm{a}}$ \\
\hline \multirow{2}{*}{ 21day } & OPG & $400.00 \pm 31.24^{\mathrm{a}}$ & $108.60 \pm 17.21^{\mathrm{b}}$ & $156.00 \pm 8.63^{b}$ & $105.21 \pm 5.360^{\mathrm{b}}$ \\
\hline & OPGR\% & - & 71.26 & 60.20 & 71.33 \\
\hline \multirow{2}{*}{ 22day } & OPG & $600.00 \pm 24.36^{\mathrm{a}}$ & $185.20 \pm 20.32^{b}$ & $265.00 \pm 41.23^{b}$ & $142.32 \pm 8.210^{\mathrm{b}}$ \\
\hline & OPGR\% & - & 51.005 & 32.39 & 61.22 \\
\hline \multirow{2}{*}{ 23day } & OPG & $436.20 \pm 22.14^{a}$ & $165.10 \pm 5.90^{\mathrm{b}}$ & $192.00 \pm 37.21^{\mathrm{b}}$ & $113.21 \pm 17.240^{\mathrm{b}}$ \\
\hline & OPGR $\%$ & - & 56.32 & 51.02 & 69.15 \\
\hline
\end{tabular}




\begin{tabular}{|c|c|c|c|c|c|}
\hline \multirow{2}{*}{ 24day } & OPG & $325.02 \pm 16.14^{\mathrm{a}}$ & $109.20 \pm 13.20^{\mathrm{b}}$ & $134.20 \pm 15.24^{b}$ & $62.35 \pm 12.310^{\mathrm{b}}$ \\
\hline & OPGR\% & - & 71.11 & 65.76 & 83.01 \\
\hline \multirow{2}{*}{25 day } & OPG & $247.30 \pm 14.23^{\mathrm{a}}$ & $64.20 \pm 6.21^{\mathrm{b}}$ & $71.00 \pm 8.23^{b}$ & $39.21 \pm 8.210^{\mathrm{b}}$ \\
\hline & OPGR\% & - & 83.01 & 81.88 & 94.76 \\
\hline \multirow{2}{*}{ 26day } & OPG & $125.36 \pm 23.35^{\mathrm{a}}$ & $24.30 \pm 4.35^{\mathrm{b}}$ & $27.40 \pm 7.21^{\mathrm{b}}$ & $19.21 \pm 1.980^{b}$ \\
\hline & OPGR\% & - & 93.57 & 93.01 & 98.82 \\
\hline \multirow{2}{*}{ 27day } & OPG & $61.00 \pm 5.21^{\mathrm{a}}$ & $13.20 \pm 1.35^{\mathrm{b}}$ & $15.30 \pm 4.56^{\mathrm{b}}$ & $4.30 \pm 0.540^{\mathrm{b}}$ \\
\hline & OPGR\% & - & 96.50 & 96.09 & 99.30 \\
\hline \multirow{2}{*}{ 28day } & OPG & $65.12 \pm 4.23^{\mathrm{a}}$ & $4.99 \pm 0.87^{\mathrm{b}}$ & $5.02 \pm 2.15^{\mathrm{b}}$ & $2.54 \pm 1.170^{\mathrm{b}}$ \\
\hline & OPGR\% & - & 98.67 & 98.71 & 99.7 \\
\hline \multirow{2}{*}{ 29day } & OPG & $64.20 \pm 12.31^{\mathrm{a}}$ & $1.15 \pm 0.02^{\mathrm{b}}$ & $1.17 \pm 0.35^{\mathrm{b}}$ & $1.10 \pm 0.360^{\mathrm{b}}$ \\
\hline & OPGR\% & - & 99.69 & 99.70 & 99.75 \\
\hline \multirow{2}{*}{ 30day } & OPG & $43.21 \pm 4.15^{\mathrm{a}}$ & $1.01 \pm 0.03^{\mathrm{b}}$ & $1.02 \pm 0.58^{b}$ & $0.91 \pm 0.210^{\mathrm{b}}$ \\
\hline & OPGR\% & - & 99.73 & 99.73 & 100 \\
\hline \multirow{2}{*}{ 31day } & OPG & $23.40 \pm 3.15^{\mathrm{a}}$ & $0.52 \pm 0.14^{b}$ & $0.65 \pm 0.21^{b}$ & $0.00 \pm 0.000^{\mathrm{b}}$ \\
\hline & OPGR\% & - & 99.86 & 99.83 & 100 \\
\hline \multirow{2}{*}{ 32day } & OPG & $13.20 \pm 0.56^{\mathrm{a}}$ & $0.21 \pm 0.20^{\mathrm{b}}$ & $0.32 \pm 0.14^{b}$ & $0.00 \pm 0.000^{\mathrm{b}}$ \\
\hline & OPGR\% & - & 99.94 & 99.91 & 100 \\
\hline \multirow{2}{*}{ 33day } & OPG & $10.00 \pm 0.01^{\mathrm{a}}$ & $0.00 \pm 0.00^{\mathrm{b}}$ & $0.00 \pm 0.00^{b}$ & $0.00 \pm 0.000^{\mathrm{b}}$ \\
\hline & OPGR\% & - & 100 & 100 & 100 \\
\hline
\end{tabular}

TABLE 4. Hematological parameters (mean $\pm \mathrm{SD}$ ) in control and treated groups at day 23 of age

\begin{tabular}{|c|c|c|c|c|c|}
\hline \multirow[b]{2}{*}{ Parameters } & \multirow[b]{2}{*}{$\mathrm{G}_{1}$} & \multirow[b]{2}{*}{$\mathrm{G}_{2}$} & \multicolumn{3}{|c|}{ Groups } \\
\hline & & & $\mathrm{G}_{3}$ & $\mathrm{G}_{4}$ & $\mathrm{G}_{5}$ \\
\hline $\operatorname{RBCs}(\times 106 / \mu \mathrm{L})$ & $2.72 \pm 0.09^{\mathrm{a}}$ & $2.41 \pm 0.01^{\mathrm{b}}$ & $2.25 \pm 0.01^{\mathrm{b}}$ & $2.3 \pm 0.03^{\mathrm{b}}$ & $1.44 \pm 0.13^{\mathrm{c}}$ \\
\hline $\mathrm{Hb}(\mathrm{g} / \mathrm{dl})$ & $9.88 \pm 0.14^{\mathrm{a}}$ & $7.95 \pm 0.03^{\mathrm{b}}$ & $6.8 \pm 0.01^{\mathrm{d}}$ & $7.5 \pm 0.09^{\mathrm{c}}$ & $5.18 \pm 0.11^{\mathrm{e}}$ \\
\hline PCV (\%) & $33.46 \pm 0.38^{\mathrm{a}}$ & $27.17 \pm 0.09^{\mathrm{b}}$ & $24.65 \pm 0.04^{\mathrm{d}}$ & $26.06 \pm 0.25^{\mathrm{c}}$ & $23.25 \pm 0.45^{\mathrm{e}}$ \\
\hline WBCs $(\times 103 / \mu \mathrm{L})$ & $14.24 \pm 0.82^{\mathrm{c}}$ & $16.88 \pm 0.24^{b}$ & $17.88 \pm 1.02^{\mathrm{b}}$ & $17.55 \pm 0.21^{\mathrm{b}}$ & $19.78 \pm 0.41^{\mathrm{a}}$ \\
\hline Lymphocyte (\%) & $58.24 \pm 0.49^{\mathrm{b}}$ & $60.5 \pm 0.16^{\mathrm{b}}$ & $59.53 \pm 0.29^{b}$ & $60.92 \pm 0.82^{b}$ & $65.2 \pm 1.59^{\mathrm{a}}$ \\
\hline Heterophil (\%) & $33.62 \pm 0.45^{\mathrm{c}}$ & $35.1 \pm 1.52^{\mathrm{b}, \mathrm{c}}$ & $36.77 \pm 1.73^{\mathrm{a}, \mathrm{b}}$ & $35.9 \pm 0.39^{b, c}$ & $39.73 \pm 0.94^{\mathrm{a}}$ \\
\hline Eosinophil (\%) & $3.53 \pm 0.23^{\mathrm{d}, \mathrm{e}}$ & $4.8 \pm 0.59^{\mathrm{b}, \mathrm{d}}$ & $6.1 \pm 0.58^{\mathrm{a}, \mathrm{b}}$ & $5.3 \pm 0.52^{\mathrm{b}, \mathrm{c}}$ & $7.2 \pm 0.25^{\mathrm{a}}$ \\
\hline Monocyte (\%) & $3.4 \pm 0.29^{\mathrm{c}, \mathrm{d}}$ & $4.35 \pm 0.38^{\mathrm{b}, \mathrm{c}, \mathrm{d}}$ & $5.4 \pm 0.59^{\mathrm{a}, \mathrm{b}}$ & $4.62 \pm 0.64^{b, c}$ & $6.6 \pm 0.29^{\mathrm{a}}$ \\
\hline
\end{tabular}

Means within rows with different superscripts differ at $P \leq 0.05 . \mathrm{G}_{1}$ : Non-infected non-treated. $\mathrm{G}_{2}$ : Infected non-treated. $\mathrm{G}_{3}$ : Infected, treated by toltrazuril. $\mathrm{G}_{4}$ : Infected, treated by sulfaclozine sodium. $\mathrm{G}_{5}$ : Infected, treated by toltrazuril + sulfaclozine sodium 
TABLE 5. Hematological parameters (mean \pm SD) in control and treated groups at day 37 of age

\begin{tabular}{cccccc}
\hline & \multicolumn{5}{c}{ Groups } \\
\cline { 2 - 5 } Parameters & $\mathrm{G}_{1}$ & $\mathrm{G}_{2}$ & $\mathrm{G}_{3}$ & $\mathrm{G}_{4}$ & $\mathrm{G}_{5}$ \\
\hline RBCs $(\times 106 / \mu \mathrm{L})$ & $2.85 \pm 0.04^{\mathrm{a}}$ & $1.88 \pm 0.12^{\mathrm{b}}$ & $2.83 \pm 0.01^{\mathrm{a}}$ & $2.81 \pm 0.02^{\mathrm{a}}$ & $2.84 \pm 0.03^{\mathrm{a}}$ \\
$\mathrm{Hb}(\mathrm{g} / \mathrm{dl})$ & $9.75 \pm 0.09^{\mathrm{a}}$ & $6.06 \pm 0.07^{\mathrm{e}}$ & $8.32 \pm 0.04^{\mathrm{c}}$ & $7.7 \pm 0.17^{\mathrm{d}}$ & $8.94 \pm 0.03^{\mathrm{b}}$ \\
PCV (\%) & $33.63 \pm 0.15^{\mathrm{a}}$ & $25.07 \pm 0.31^{\mathrm{d}}$ & $28.57 \pm 0.06^{\mathrm{b}}$ & $25.99 \pm 0.3^{\mathrm{c}}$ & $28.84 \pm 0.09^{\mathrm{b}}$ \\
WBCs $(\times 103 / \mu \mathrm{L})$ & $14.32 \pm 0.22^{\mathrm{b}}$ & $17.25 \pm 0.62^{\mathrm{a}}$ & $15.14 \pm 0.98^{\mathrm{b}}$ & $15.88 \pm 0.35^{\mathrm{a}, \mathrm{b}}$ & $15.12 \pm 0.73^{\mathrm{b}}$ \\
Lymphocyte $(\%)$ & $58.47 \pm 0.98^{\mathrm{a}}$ & $60.15 \pm 1.95^{\mathrm{a}}$ & $59 \pm 1.4^{\mathrm{a}}$ & $59.1 \pm 0.92^{\mathrm{a}}$ & $58.93 \pm 1.17^{\mathrm{a}}$ \\
Heterophil $(\%)$ & $34.17 \pm 0.65^{\mathrm{a}}$ & $35.21 \pm 0.97^{\mathrm{a}}$ & $34.71 \pm 1.53^{\mathrm{a}}$ & $34.95 \pm 0.65^{\mathrm{a}}$ & $34.6 \pm 1.88^{\mathrm{a}}$ \\
Eosinophil $(\%)$ & $3.54 \pm 0.59^{\mathrm{b}}$ & $5.67 \pm 0.3^{\mathrm{a}}$ & $3.57 \pm 0.47^{\mathrm{b}}$ & $3.6 \pm 0.49^{\mathrm{b}}$ & $3.57 \pm 0.49^{\mathrm{b}}$
\end{tabular}

Means within rows with different superscripts differ at $P \leq 0.05 . \mathrm{G}_{1}$ : Non-infected non-treated. $\mathrm{G}_{2}$ : Infected non-treated. $\mathrm{G}_{3}$ : Infected, treated by toltrazuril. $\mathrm{G}_{4}$ : Infected, treated by sulfaclozine sodium. $\mathrm{G}_{5}$ : Infected, treated by toltrazuril and sulfaclozine sodium

TABLE 6. Biochemical parameters (mean \pm SD) in control and treated groups at day 23 of age

\begin{tabular}{cccccc}
\hline & \multicolumn{5}{c}{ Groups } \\
\cline { 2 - 6 } Parameters & $\mathrm{G}_{1}$ & $\mathrm{G}_{2}$ & $\mathrm{G}_{3}$ & $\mathrm{G}_{4}$ & $\mathrm{G}_{5}$ \\
\hline AST (U/L) & $43 \pm 0.0^{2} \mathrm{e}$ & $92.1 \pm 0.36^{\mathrm{a}}$ & $74.1 \pm 0.3^{\mathrm{d}}$ & $76.7 \pm 0.35^{\mathrm{c}}$ & $80 \pm 0.08^{\mathrm{b}}$ \\
ALT (U/L) & $40 \pm 0.6^{6} \mathrm{~d}$ & $88.9 \pm 0.68 \mathrm{a}$ & $69 \pm 0.74^{\mathrm{c}}$ & $70 \pm 0.8^{7} \mathrm{c}$ & $73 \pm 0.39^{\mathrm{b}}$ \\
ALP (U/dl) & $43.76 \pm 0.0^{\mathrm{e}} \mathrm{c}$ & $93.2 \pm 0.01^{\mathrm{a}}$ & $76.1 \pm 0.04^{\mathrm{d}}$ & $77.6 \pm 0.04^{\mathrm{c}}$ & $79.5 \pm 0.01^{\mathrm{b}}$ \\
TP (g/dl) & $3.51 \pm 0.03^{\mathrm{a}}$ & $1 \pm 0.06^{\mathrm{e}}$ & $1.9 \pm 0.06^{\mathrm{b}, \mathrm{c}}$ & $1.78 \pm 0.01^{\mathrm{c}, \mathrm{d}}$ & $1.69 \pm 0.06^{\mathrm{d}}$ \\
Albumin (g/d) & $1.93 \pm 0.03^{\mathrm{a}}$ & $0.49 \pm 0.01^{\mathrm{e}}$ & $0.72 \pm 0.01^{\mathrm{b}}$ & $0.68 \pm 0.01^{\mathrm{b}}$ & $0.61 \pm 0.02^{\mathrm{c}}$ \\
Creatinine (mg/dl) & $0.4 \pm 0.003$ & $1.69 \pm 0.04^{\mathrm{a}}$ & $0.8 \pm 0.12^{\mathrm{b}, \mathrm{c}}$ & $0.88 \pm 0.01^{\mathrm{b}, \mathrm{c}}$ & $0.95 \pm 0.09^{\mathrm{b}}$ \\
Uric acid (mg/dl) & $6.9 \pm 0.051$ & $9.9 \pm 0.0^{8} \mathrm{a}$ & $8.3 \pm 0.0^{4 \mathrm{c},} \mathrm{d}$ & $8.5 \pm 0.01^{\mathrm{b}, \mathrm{c}}$ & $8.7 \pm 0.06^{\mathrm{b}}$ \\
\hline
\end{tabular}

Means within rows with different superscripts differ at $P \leq 0.05 . \mathrm{G}_{1}$ : Non-infected non-treated. $\mathrm{G}_{2}$ : Infected non-treated. $\mathrm{G}_{3}$ : Infected, treated by toltrazuril. $\mathrm{G}_{4}$ : Infected, treated by sulfaclozine sodium. $\mathrm{G}_{5}$ : Infected, treated by toltrazuril and sulfaclozine sodium

TABLE 7. Biochemical parameters (mean \pm SD) in control and treated groups at day 37 of age

\begin{tabular}{cccccc}
\hline & \multicolumn{5}{c}{ Groups } \\
\cline { 2 - 6 } Parameters & $\mathrm{G}_{1}$ & $\mathrm{G}_{2}$ & $\mathrm{G}_{3}$ & $\mathrm{G}_{4}$ & $\mathrm{G}_{5}$ \\
\hline AST (U/L) & $44 \pm 0.03^{\mathrm{e}}$ & $88.6 \pm 0.04^{\mathrm{a}}$ & $70 \pm 0.02^{\mathrm{d}}$ & $73 \pm 0.15^{\mathrm{c}}$ & $75.1 \pm 0.08^{\mathrm{b}}$ \\
ALT (U/L) & $41 \pm 0.28^{\mathrm{d}}$ & $85.1 \pm 0.49^{\mathrm{a}}$ & $67.3 \pm 0.59^{\mathrm{c}}$ & $67.8 \pm 0.54^{\mathrm{c}}$ & $71.2 \pm 0.24^{\mathrm{b}}$ \\
ALP (U/d) & $44.27 \pm 0.02^{\mathrm{e}}$ & $87.9 \pm 0.03^{\mathrm{a}}$ & $68.6 \pm 0.01^{\mathrm{d}}$ & $73.2 \pm 0.05^{\mathrm{c}}$ & $75 \pm 0.01^{\mathrm{b}}$ \\
TP (g/dl) & $3.21 \pm 0.05^{\mathrm{a}}$ & $1.31 \pm 0.05^{\mathrm{d}}$ & $2.5 \pm 0.06^{\mathrm{b}}$ & $1.9 \pm 0.03^{\mathrm{c}}$ & $1.8 \pm 0.01^{\mathrm{c}}$ \\
Albumin (g/dl) & $2.03 \pm 0.01^{\mathrm{a}}$ & $0.56 \pm 0.01^{\mathrm{d}}$ & $0.78 \pm 0.01^{\mathrm{b}}$ & $0.75 \pm 0.02^{\mathrm{b}}$ & $0.64 \pm 0.01^{\mathrm{c}}$ \\
Creatinine (mg/d) & $0.5 \pm 0.1^{\mathrm{d}}$ & $1.33 \pm 0.01^{\mathrm{a}}$ & $0.7 \pm 0.01^{\mathrm{c}}$ & $0.82 \pm 0.01^{\mathrm{b}}$ & $0.89 \pm 0.01^{\mathrm{b}}$ \\
Uric acid (mg/dl) & $7 \pm 0.07^{\mathrm{c}}$ & $9 \pm 0.07^{\mathrm{a}}$ & $8 \pm 0.4^{\mathrm{b}, \mathrm{c}}$ & $8.3 \pm 0.04^{\mathrm{b}}$ & $8.4 \pm 0.05^{\mathrm{b}}$ \\
\hline
\end{tabular}

Means within rows with different superscripts differ at $P \leq 0.05 . G_{1}$ : Non-infected non-treated. $G_{2}$ : Infected non-treated. $G_{3}$ : Infected, treated by toltrazuril. $G_{4}$ : Infected, treated by sulfaclozine sodium. $\mathrm{G}_{5}$ : Infected, treated by toltrazuril and sulfaclozine sodium 

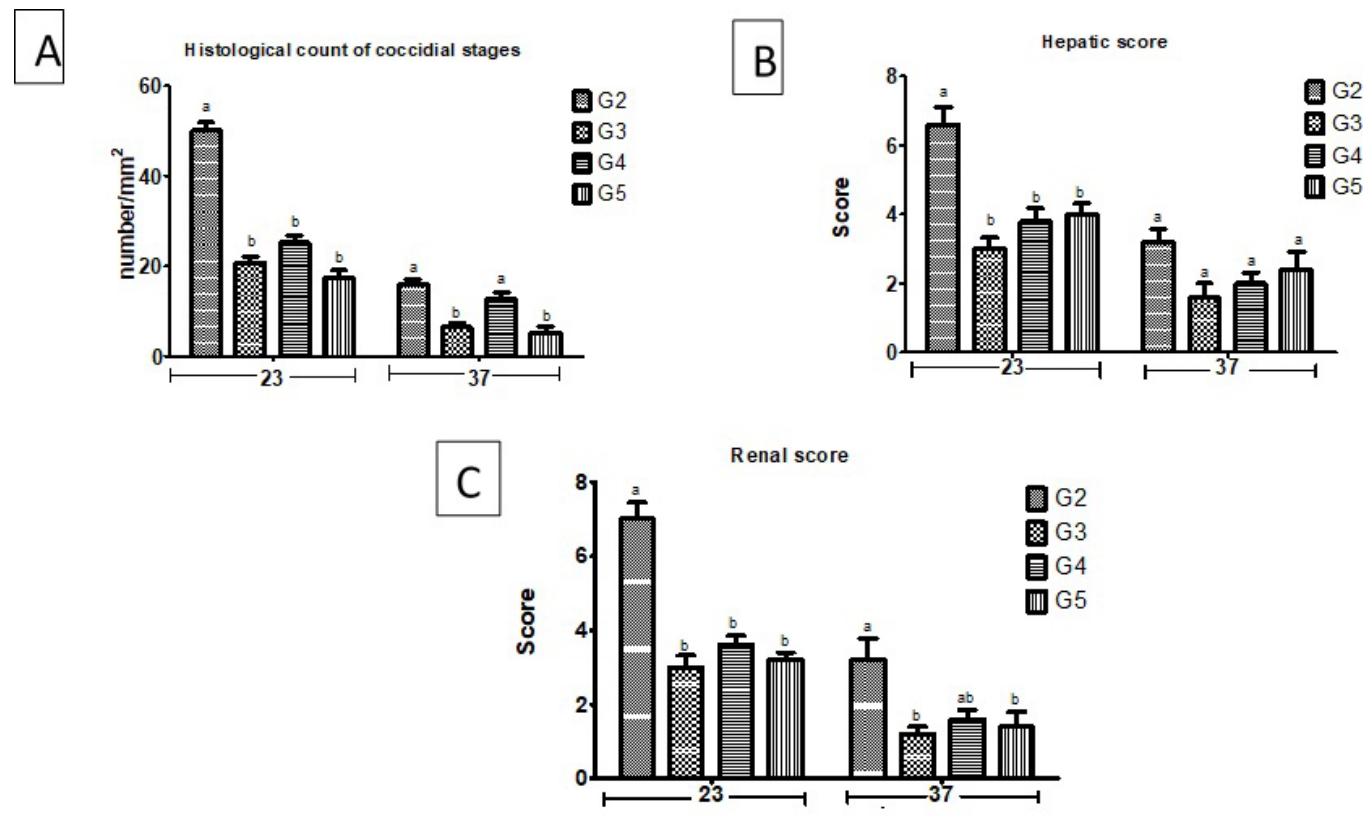

FIGURE 1. A) represents the histological count of coccidial stages, B) represents hepatic score, C) renal score. Data expressed as Means with different superscripts differ at $P \leq 0.05 . G_{2}$ : Infected non-treated. $G_{3}$ : Infected, treated by toltrazuril. $\mathrm{G}_{4}$ : Infected, treated by sulfaclozine sodium. $\mathrm{G}_{5}$ : Infected, treated by toltrazuril and sulfaclozine sodium

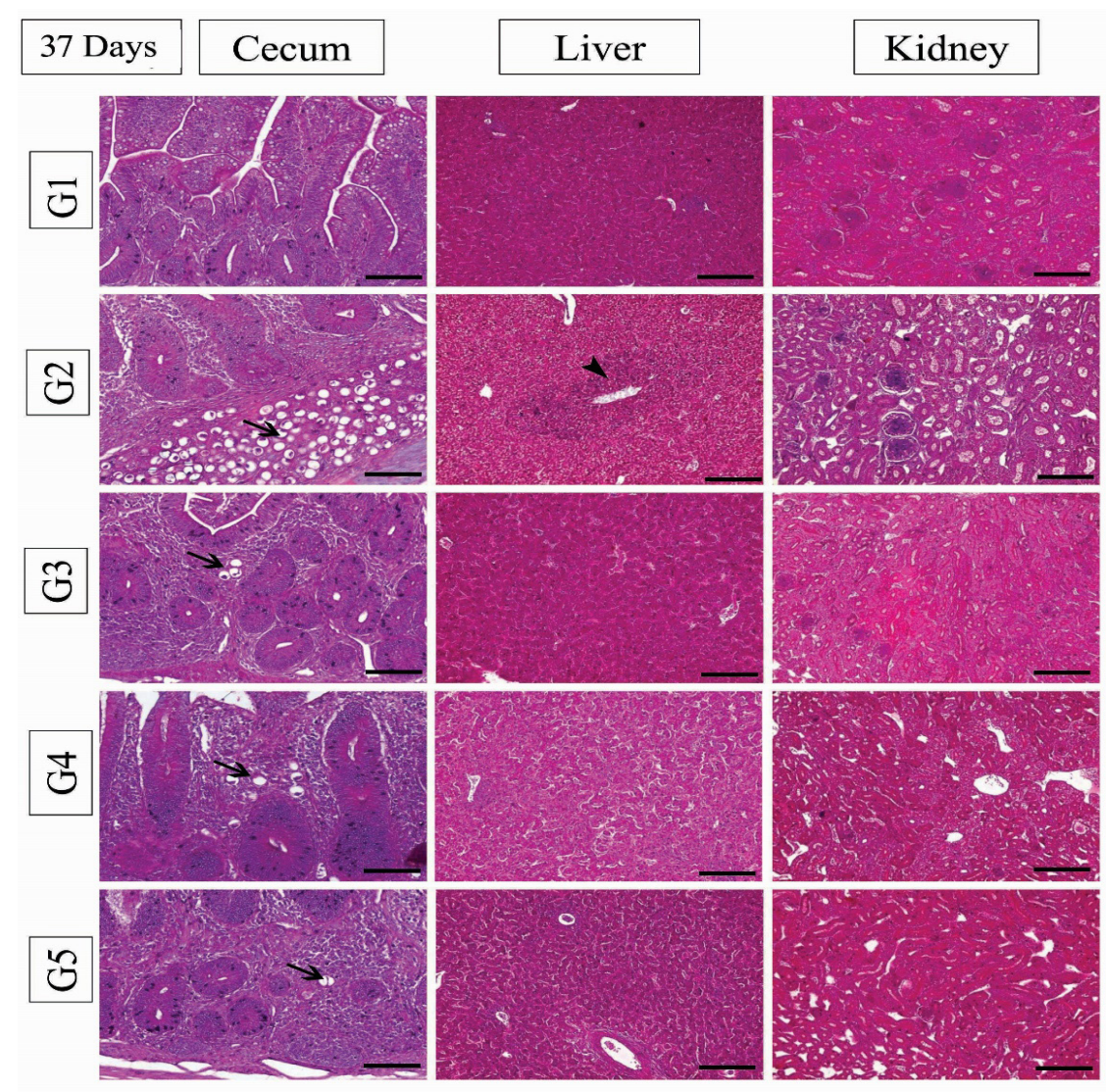

FIGURE 2. Histopathological findings of the cecal, hepatic, and renal tissues of the different groups sacrificed on the 23rd day. The first lane represents the cecum, liver and kidney of G1, 2nd lane represents the cecum, liver and kidney of G2, 3rd lane represents the cecum, liver and kidney of G3, 4th lane represents the cecum, liver and kidney of G4, 5th lane represents the cecum, liver and kidney of G5. Arrows indicate parasitic stages; arrowheads reveal periportal inflammatory cells infiltration and curved-arrow shows necrotic and degenerative changes within the renal tubules, bar $=100 \mu \mathrm{m}$ 


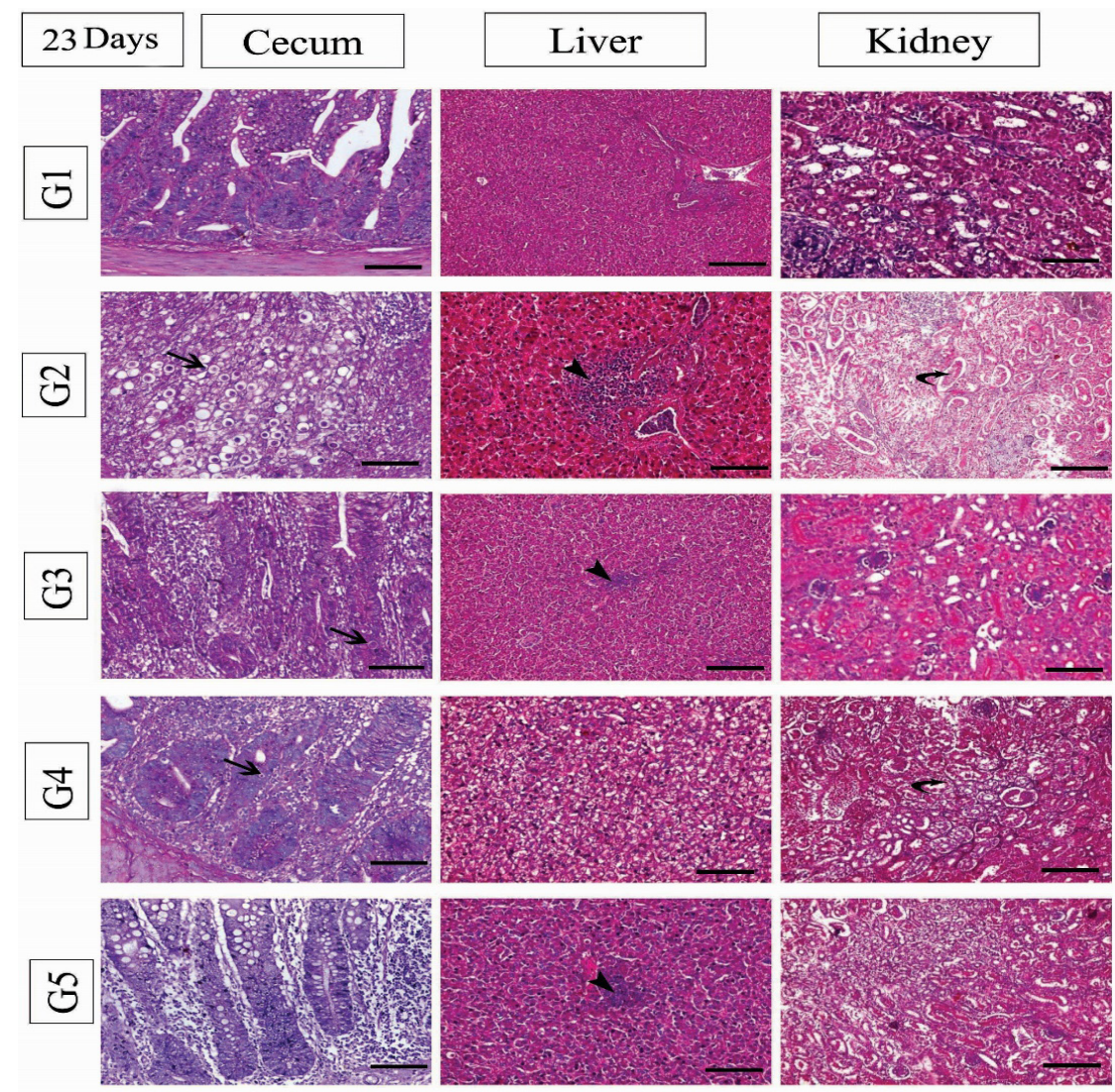

FIGURE 3. Histopathological findings of the cecal, hepatic, and renal tissues of the different groups sacrificed on the $37^{\text {th }}$ day. The first lane represents the cecum, liver, and kidney of $\mathrm{G}_{1}, 2^{\text {nd }}$ lane represents the cecum, liver and kidney of $\mathrm{G}_{2}, 3^{\text {rd }}$ lane represents the cecum, liver and kidney of $\mathrm{G}_{3}, 4^{\text {th }}$ lane represents the cecum, liver and kidney of $\mathrm{G}_{4}, 5^{\text {th }}$ lane represents the cecum, liver and kidney of $\mathrm{G}_{5}$. Arrows indicate parasitic stages; arrowheads show periportal inflammatory cells infiltration and curved-arrow shows necrotic and degenerative changes within the renal tubules, bar $=100 \mu \mathrm{m}$

\section{DISCUSSION}

Toltrazuril and sulfaclozine sodium blocked the production of coccidia stages in the cecum, which in turn reduced the number of oocysts in feces. Toltrazuril is effective against all intracellular developmental stages including those of schizogony and gametogenic (Mehlhorn et al. 1988). Toltrazuril enhances natural immunity (Greif 2000). Due to antibacterial activity, the sulfonamide drug prevents secondary bacterial infections, which often occur after coccidiosis (Yegani $\&$ Korver 2008). Sulfaclozine sodium may reduce the deleterious effects of coccidiosis in broilers (Ashraf 2011). It interferes with the synthesis of folic acid, which required for deoxyribonucleic acid synthesis (Haritova et al. 2013). Therefore, toltrazuril when used alone, or in combination with sulfaclozine sodium, has a potent anticoccidial effect and improved body weight gain. In addition, the slight clinical manifestation of illness all over the experimental period, decreased lesion score and oocyst output was observed (Ashraf 2011; Lovelu et al. 2016).
Infection with $E$. tenella induced a significant decrease in $\mathrm{RBCs}, \mathrm{Hb}$, and PCV; this may be due to the profuse cecal hemorrhages caused by E. tenella infection, which leads to anemia. It also induced a significant increase in total leucocytic count and differential leucocytic count as (lymphocytosis, heterophilia, monocytosis, and eosinophilia). These hematological findings were in agreement with Adamu et al. (2013) and Akhtar et al. (2015). Increase in leucocytic count expressed as lymphocytosis, heterophilia, monocytosis, and eosinophilia confirmed by Bremner (2018) who stated that heterophils are the major phagocytic cells in the population of leucocytes, mast cells could play a role primary inflammatory cells, eosinophils which mainly increased during parasitic infestation, monocytes as $2^{\text {nd }}$ line of defense increased in case of protozoal infection and lymphocytes which consider as a wandering cells by migration during the inflammatory immune response. Moreover, hematological parameters markedly improved in toltrazuril and toltrazuril plus sulfaclozine sodium 
treated groups than sulfaclozine sodium only treated group. Similar improvement in hematological parameters was also recorded by Harfoush et al. (2010) and Youssef et al. (2015).

A significant increase in serum ALT, AST, ALP, uric acid, and creatinine and a significant decrease in total protein and albumin in infected non treated group may be due to the impaired liver function and injury of liver and kidney parenchyma due to harmful effect of Eimeria parasite. These findings are following those obtained by Harfoush et al. (2010) who found that infection with $E$. tenella showed unexpected increase in ALT and AST. This noticed that although Eimeria infection might not have a direct effect on the liver. On the other hand, more support could be obtained from the fact that Eimeria caused diarrhea and favors secondary bacterial infection like clostridia and their toxins may affect the enzymes of the liver. The liver is considered the precursor of most serum protein. Generally, hypoproteinimia occurs in chronic renal, hepatic diseases, malnutrition, and malabsorption of nutrients. In the present study, the pattern of total protein and albumin indicates hypoprotienimia which may be attributed to AL-Saeed et al. (2017) and El-Maksoud et al. (2014).

Moreover, Mondal et al. (2011) and Patra et al. (2010) reported that, liver function test of the infected broiler chickens with Eimeria spp. showed a significant increase in the serum ALT, AST. They suggested that significant damage of cell lining of the cecal wall along with their inflammation, severe blood loss causing tissue loss from the body may attribute to increased AST activity, and the fall in total plasma protein in the coccidia infected birds might be due to acute stress that leads to cortisol secretion and catabolism of protein. The noticeably increased serum activities of ALP in our study might be associated with the metabolic alteration and damage of the bone marrow as compensation for the blood losses; the bone marrow might force to produce excessive blood cellular components. Alkaline phosphatase found mainly in the bone, liver, and intestinal wall, with high levels found in young animals with high osteoblastic activity (Kerr 2008). The changes in the biochemical parameters were significantly improved in toltrazuril treated group than sulfaclozine sodium, toltrazuril plus sulfaclozine sodium groups.

Histopathological findings in $\mathrm{G}_{2}$ were in agreement with Bould et al. (2009) who reported that this severe destruction in cecal mucosal layer, penetrating villus epithelial cells resulting in extensive desquamation of the cecal epithelium and hemorrhagic feces due to the initial adherence and invasion of E. tenella to the intestinal epithelium of the host cells which must occur across this mucus interface. At the end of the experiment, we observed the capacity of cecal mucosa to repair itself. This might be explained by developing the chronic stage when the host can modulate its defensive mechanisms through enhancing local mucosa immune responses, and this assumption could be proofed by Khalafalla (2009) who cleared that in the absence of reinfection, the life cycle of the parasite in an infected host is self-limiting as a result of building up of immunity during propagation of infective agents through the course of the disease and/or a result of repeated infection. $\mathrm{G}_{3}, \mathrm{G}_{4}$, and $\mathrm{G}_{5}$ showed absence of any developmental stages of $E$. tenella accompanied by mild degenerative and hyperplastic changes with the mucosa, these finding agree with Ashraf (2011). The histopathological examination of liver and kidney samples collected from $\mathrm{G}_{2}$ showed multifocal periportal inflammation consisted of mononuclear cells infiltration mixed with eosinophils and coagulative necrosis of the renal tubules, these finding agree with finding reported by Saber (1995). The hepatic and kidney samples from $\mathrm{G}_{3}, \mathrm{G}_{4}$, and $\mathrm{G}_{5}$ showed mild to moderate periportal inflammatory cells infiltration and degenerative changes of renal tubules epithelium. There was an improvement in livers and kidneys of $\mathrm{G}_{3}, \mathrm{G}_{4}$, and $\mathrm{G}_{5}$ ) in comparison with $\mathrm{G}_{2}$.

\section{CONCLUSION}

Through this trials, the use of toltrazuril alone and in combination with sulfaclozine was able to control experimental caecal coccidian infection in chickens. The combined use of both drugs can be proven to better manage the infection adequately due to the improved effect of both drugs. But this result needs to be further investigated in the other species of coccidia that infect chickens.

\section{ACKNOWLEDGEMENTS}

The authors are grateful to Prof. Abo El-Nasr Ahmed Zahra, Department of Pharmacology, Faculty of Veterinary Medicine, Kafrelsheikh University, for providing Kimzuril 2.5\%, sulfaclozimed 30\% and standard broiler ration free from any anticoccidial drugs.

\section{REFERENCES}

Abbas, A., Iqbal, Z., Abbas, R.Z., Khan, M.K., Khan, J.A., Sindhu, Z.U.D., Mahmood, M.S. \& Saleemi, M.K. 2017. In vivo anticoccidial effects of Beta vulgaris (sugar beet) in broiler chickens. Microbial Pathogenesis 111: 139-144.

Adamu, M., Boonkaewwan, C., Gongruttananun, N. \& Vongpakorn, M. 2013. Hematological, biochemical and histopathological changes caused by coccidiosis in chickens. Kasetsart Journal - Natural Science 47(2): 238246.

Akhtar, M., Awais, M.M., Anwar, M.I., Ehtisham-ul-Haque, S., Nasir, A., Saleemi, M.K. \& Ashraf, K. 2015. The effect of infection with mixed Eimeria species on hematology and immune responses following Newcastle disease and infectious bursal disease booster vaccination in broilers. The Veterinary Quarterly 35(1): 21-26. 
AL-Saeed, M.H., AL-Saeed, A.H. \& Jori, M.M. 2017. Study of physiological and histological changes in rabbits induced with hepatic coccidiosis. Journal of Kerbala University 13(1): 217-228.

Ashraf, M. 2011. Evaluation of therapeutic and prophylactic potentials of toltrazuril against caecal coccidiosis of chickens in Bangladesh. PhD dissertation, Master of Sciences Thesis. Bangladesh Agricultural University, Mymensingh, Bangladesh (Unpublished).

Barham, D. \& Trinder, P. 1972. An improved colour reagent for the determination of blood glucose by the oxidase system. Analyst 97(1151): 142-145.

Bould, J.G., Elsheikha, H.M. \& Morsy, T.A. 2009. Avian coccidiosis: The basic pathology to control. Journal of the Egyptian Society of Parasitology 39(1(: 85-98.

Bremner, A. 2018. Innate responses and biomarkers of resistance to Eimeria infection in the chicken. Edinburgh Research Archive. https://era.ed.ac.uk/handle/1842/28939.

Chand, N., Faheem, H., Khan, R.U., Qureshi, M.S., Alhidary, I.A. \& Abudabos, A.M. 2016. Anticoccidial effect of mananoligosacharide against experimentally induced coccidiosis in broiler. Environmental Science and Pollution Research 23(14): 14414-14421.

Doumas, B.T., Watson, W.A. \& Biggs, H.G. 1971. Albumin standards and the measurement of serum albumin with bromcresol green. Clinica Chimica Acta 31(1): 87-96.

Eckert, J., Taylor, M., Catchpole, J., Licois, D., Coudert, P. \& Bucklar, H. 1995. Identification of Eimeria species and strains. Morphological characteristics of oocysts. In Biotechnology: Guidelines on Techniques in Coccidiosis Research. Luxembourg: Office for Official Publications of the European Communities. pp. 113-116.

El-Ghoneimy, A. \& El-Shahawy, I. 2017. Evaluation of amprolium and toltrazuril efficacy in controlling natural intestinal rabbit coccidiosis. Iranian Journal of Veterinary Research 18(3): 164-169.

El-Maksoud, A., Afaf, H., Abdel-Magid, D. \& El-Badry, M. 2014. Biochemical effect of Coccidia infestation in laying hen. Benha Veterinary Medical Journal 26(1): 127-133.

Greif, G. 2000. Immunity to coccidiosis after treatment with toltrazuril. Parasitology Research 86(10): 787-790.

Harfoush, M.A., Hegazy, A.M, Soliman, A.H. \& Amer, S. 2010. Drug resistance evaluation of some commonly used anticoccidial drugs in broiler chickens. Journal of the Egyptian Society of Parasitology 40(2): 337-348.

Haritova, A.M., Lashev, L.D. \& Koinarski, V.C. 2013. Sulfachloropyrazine disposition in Eimeria tenella infected chickens. Veterinarski Arhiv. 83(2): 211-222.

Harrison, G.J. \& Harrison, L.R. 1986. Clinical Avian Medicine and Surgery. Philadelphia, London, Torono. W.B. Saunders Company.

Henry, R.J. 1974. Clinical Chemistry Principles and Techniques. 2nd ed. New York, USA: Harper and Row Publication.

Henry, R.J. 1964. Colorimetric Determination of Total Protein. Clinical Chemistry. New York, USA: Harper and Row Publication.

Johnson, J. \& Reid, W.M. 1970. Anticoccidial drugs: Lesion scoring techniques in battery and floor-pen experiments with chickens. Experimental Parasitology 28(1): 30-36.
Kerr, M.G. 2008. Veterinary Laboratory Medicine: Clinical Biochemistry and Haematology. Oxford: John Wiley \& Sons.

Khalafalla, R.E.-B.I. 2009. Evaluation of inhibition of Eimeria tenella sporozoites by antibody fragments expressed in pea. Universität Leipzig, Leipzig, Ph.D. Dissertation (Unpublished).

Kind, P.R.N. \& King, E.J. 1954. Estimation of plasma phosphatase by determination of hydrolysed phenol with amino-antipyrine. Journal of Clinical Pathology 7(4): 322326.

Li, Y. \& Bu, S. 2014. A simple and sensitive UHPLC-MS/ MS method for the determination of sulfachloropyrazine sodium in chicken plasma and application in a comparative pharmacokinetic study. Analytical Methods 6(18): 73127317.

Lloyd, S. \& Soulsby, E.J.L. 1978. Survey of parasites in dairy goats. American Journal of Veterinary Research 39(6): 1057-1059.

Lovelu, M.A., Talukder, M.H., Alam, M.Z. \& Karim, M.A. 2016. Evaluation of anti-coccidial drug sensitivity against experimental coccidiosis in broiler chicks. Journal of the Bangladesh Agricultural University 14(1): 57-61.

Mcdougald, L.R. \& Fitz-Coy, S. 2008. Coccidiosis. In Diseases of Poultry, edited by Saif, Y.M. 12th ed. Ames, IA, USA: Iowa State University Press.

Mehlhorn, H., Schmahl, G. \& Haberkorn, A. 1988. Toltrazuril effective against a broad spectrum of protozoan parasites. Parasitology Research 75(1): 64-66.

Mondal, D.K., Chattopadhyay, S., Batabyal, S., Bera, A.K. \& Bhattacharya, D. 2011. Plasma biochemical indices at various stages of infection with a field isolate of Eimeria tenella in broiler chicken. Veterinary World 4(9): 404-409.

Moskey, H.E. \& Harwood, P.D. 1941. Methods of evaluating the efficacy of anthelmintics. American Journal of Veterinary Research 2(2): 55-59.

Patra, G., Ali, M.A., Chanu, K.V., Jonathan, L., Joy, L.K., Prava, M., Ravindran, R., Das, G. \& Devi, L.I. 2010. PCR based diagnosis of Eimeria tenella infection in broiler chicken. International Journal of Poultry Science 9(8): 813-818.

Pop, L., Györke, A., Tăbăran, A.F., Dumitrache, M.O., Kalmár, Z., Magdaş, C., Mircean, V., Zagon, D., Balea, A. \& Cozma, V. 2015. Effects of artemisinin in broiler chickens challenged with Eimeria acervulina, E. maxima and E. tenella in battery trials. Veterinary Parasitology 214(3-4): 264-271.

Ramadan, A., El-Sooud, K.A. \& El-Bahy, M.M. 1997. Anticoccidial efficacy of toltrazuril and halofuginone against Eimeria tenella infection in broiler chickens in Egypt. Research in Veterinary Science 62(2): 175-178.

Reagan, W.J., Rovira, A.R.I. \& DeNicola, D.B. 2019. Veterinary Hematology: Atlas of Common Domestic and Non-Domestic Species. Chichester: John Wiley \& Sons.

Reitman, S. \& Frankel, S. 1957. A colorimetric method for the determination of serum glutamic oxalacetic and glutamic pyruvic transaminases. American Journal of Clinical Pathology 28(1): 56-63.

Saber, M.M. 1995. Pharmacological studies on some anticoccidial drugs in chickens. M.V.Sc. Thesis. Zagazig University, Egypt (Unpublished). 
Shivaramaiah, C., Barta, J.R., Hernandez-Velasco, X., Téllez, G. \& Hargis, B.M. 2014. Coccidiosis: Recent advancements in the immunobiology of Eimeria species, preventive measures, and the importance of vaccination as a control tool against these Apicomplexan parasites. Veterinary Medicine 5(5): 23-34.

Tewari, A.K. \& Maharana, B.R. 2011. Control of poultry coccidiosis: Changing trends. Journal of Parasitic Diseases 35(1): 10-17.

Xie, M., Cai, J., Li, A. \& Peng, X. 2001. Coccidiosis of domestic fowl in China. In Proceedings of the VIIIth International Coccidiosis Conference. Palm Cove, Sydney, Australia. pp. 153-154.

Yegani, M. \& Korver, D.R. 2008. Factors affecting intestinal health in poultry. Poultry Science 87(10): 2052-2063.

Youssef, F.M.A., El-Hamid, H.A.A. \& El Sheshtawy, E.A. 2015.

Clinicopathological studies on the effect of Artemisia cina (sheih baladi) on coccidiosis in chickens. Egyptian Journal of Veterinary Sciences 46(1): 11-24.

Dina Hagag*

Department of Pharmacology

Animal Health Research Institute (ARC)

Kafrelsheikh University

Egypt

Kamal El-Shazly, Magdy Abd El-Aziz \& Amira Abd El-Latif

Department of Pharmacology

Faculty of Veterinary Medicine

Kafrelsheikh University

Egypt
Hanem El-Sharkaway

Department of Poultry Disease

Faculty of Veterinary Medicine

Kafrelsheikh University

Egypt

Walied Abdo

Department of Pathology

Faculty of Veterinary Medicine

Kafrelsheikh University

Egypt

Mohamed Barakat

Department of Biochemistry

Animal Health Research Institute (ARC)

Kafrelsheikh University

Egypt

*Corresponding author; email: dinahagag1991@gmail.com

Received: 1 March 2020

Accepted: 25 May 2020 